UDC 621.315 .592

S. S. Kulikov, YE. V. Brytavskyi, V. A. Borshchak, N. P. Zatovskaya, M. I. Kutalova, Y. N. Karakis

Odessa I. I. Mechnikov National University, 42, Pastera Str; phone: 723-34-61 .

\title{
THE STUDY OF HOMOGENEOUS AND HETEROGENEOUS SENSITIZED CRYSTALS OF CADMIUM SULFIDE. PART III. OSCILLATIONS OF EXCITED CARRIERS
}

The processes at short-wave limit of the quenching of the photocurrent were studied. The possibility of creating a new type of device - a sensitive photometer (not on the intensity of light, but on its wavelength), and the combined temperature-voltage tester.

The process of hole oscillation under photoexcitation from R-centers is investigated. The quantum yield for infrared light is determined. The effect of the applied voltage on the form of the spectral distribution curves of the photocurrent quenching was found and explained. The concentration of R-centers in the samples is calculated.

This publication is a continuation of the reviews [1-2]. For the sake of preservation of generality of work continuous numbering of sections is chosen. Numbers of formulas and figures are presented by sections. References in each article are given individually.

Cadmium sulfide crystals are used in our studies as a convenient model material. Obtained results and constructed models are also applied to other semiconductors.

\section{Research of processes in the field of short- wave threshold of infrared quenching of photocurrent}

Lets consider, that in a sensitive crystal under the action of light, the wavelength of which does not change from the maximum of its own excitation $(520 \mathrm{~nm})$, a photocurrent $I_{\text {excit }}$ is formed. If at the same time the monochromatic light with controlled wavelength, hereinafter referred to as the main, is sent to sample, the quenching region of the flowing photocurrent $I_{\text {main }}$ is less than the original: $I_{\text {excit }}>I_{\text {main }}$. With a decrease in the wavelength of the main light, it will also be intristic. Then, in the conditions of additional excitation $I_{\text {main }}>I_{\text {excit. }}$

As in the long-wave part of the spectrum $I_{\text {excit }}>I_{\text {main }}$, and in the shortwave $I_{\text {main }}>I_{\text {excit. }}$ then, according to the Bolzano-Cauchy theorem, there must be a point when $I_{\text {main }}=I_{\text {excit. }}$. Let's call this wavelength as shortwave threshold for the effect of IR-quenching of photocurrent or the point of bifurcation. The switching-on of basic light in this point of spectrum does not change photocurrent $I_{\text {excit }}$ being already formed (see Fig. 4.1.B).

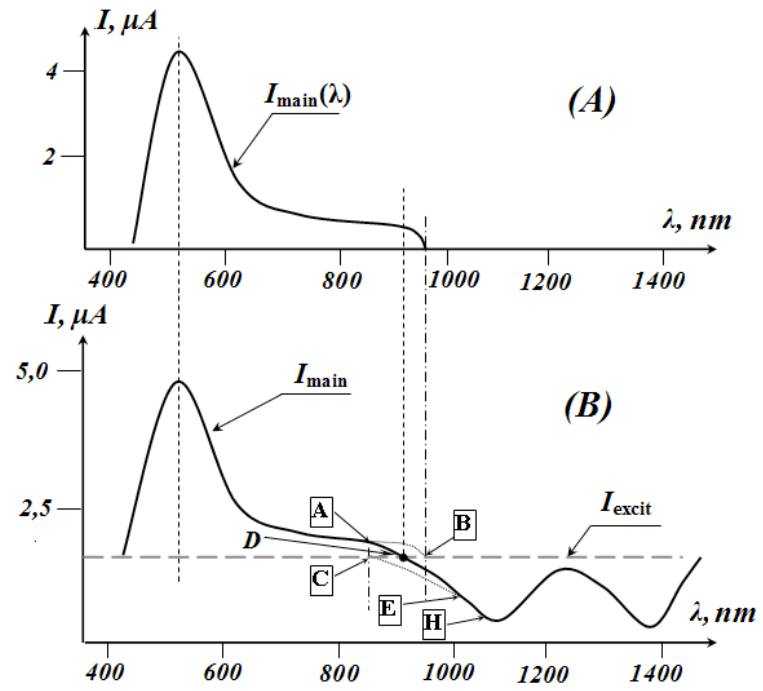

Fig. 4.1. The spectral distribution of the photocurrent under the action of only exciting light with $\lambda=520 \mathrm{~nm}$ (A) and together the main and exciting light(B).

The processes occurring in the crystal have not been studied before and are studied for the first time $[3,4]$. 


\subsection{On the balance of processes of excita- tion-quenching at the bifurcation point}

There are two options. Exposure by the main light at the bifurcation point does not cause any changes. Its wavelength is too far from the field of its intristic excitation and does not lead to an increase in the concentration of the main charge carriers. At the same time, it is too small to change the concentration of minority carriers and does not cause the IR-quenching process.

Or both processes, although to a weak degree, are activated, but are equal to each other. In the latter case, as usual, when exposed to competing mechanisms, the current must be very sensitive to changes in external conditions - temperature, applied voltage, changes in the intensity of the main and excitation light.

Figure 4.1.B shows the change in photocurrent $I_{\text {main }}$ under the action of the main light of different wavelengths. Here, for convenience, the photocurrent $I_{\text {excit }}$ generated by the action of only light with a wavelength of $520 \mathrm{~nm}$ is shown.

In the direction of large wavelengths, photosensitivity was observed up to the boundary of the infrared part of the spectrum $(\sim 900-940$ $\mathrm{nm})$. In the region of wavelengths $600-850 \mathrm{~nm}$, we observed almost a tabular part of the graph. Obviously, this area is formed due to emptying of the deep traps. These traps are also responsible for the relatively long relaxation of the photocurrent (up to 20 minutes at each point) described in chapter 3.1-3.2. All the results described below were obtained in stationary conditions. The kinetics of setting the values corresponded to [5-8].

The optimal intensity of the main and the excitation light to the curves of Fig. 4.1 in accordance with the data of Chapter 1, were selected as a baseline in the study of the effect of light fluxes on the spectral position of the bifurcation point (see below). At selected light intensities, the bifurcation point is shown in Fig. 4.1 hit at a wavelength of $930 \mathrm{~nm}$.

1. If the processes of photoexcitation ended with a wavelength earlier than the bifurcation point, and the IR-quenching effect began later than it, the graph $I_{\text {main }}(\lambda)$ would have the form shown in Fig. 4.1.B dotted line. In this case, in the vicinity of ${ }^{*} \mathrm{D}$ we would observe a more or less pronounced plateau coinciding with the value of $I_{\text {excit }}$. It is the absence of such a plateau that indicates that another possibility is being realized. In the bifurcation region, the sample is simultaneously excited by the main light and IR-quenching. At point $\mathrm{D}$, these two processes are exactly compensated.

2. Figure 4.1.A at the same scale as 4.1.B the spectral distribution of the photocurrent is shown. As can be seen from the graph, the sample showed photosensitivity, though insignificant, up to wavelengths of $\sim 1000 \mathrm{~nm}$. The appearance of a longer-wave sensitivity relative to ${ }^{*} \mathrm{D}$ is explained as follows. The wavelength of the exciting light is too long. It is poorly absorbed and the number of photoexcited carriers is small. Obviously, in these circumstances, the filling of the R-centers by holes is minimal. The IR-quenching process is difficult. We observe long-wavelength edge of photo-excitation in absence of quenching. But in this case, at the point of bifurcation, photoexcitation is more pronounced.

3. To the left of the point D curve $I_{\text {main }}(\lambda)$ changes the smoothness. Starting with wavelengths of about $880 \mathrm{~nm}$, the $I_{\text {main }}(\lambda)$ graph decreases more sharply to the bifurcation point. This can occur if the distribution of the photocurrent is already stepped in by infrared quenching.

It is impossible to measure the quenching curve in the area of the CE without excitation (similar to paragraph 2), since the quenching process essentially requires the participation of two light streams. However, this dependence can be calculated, assuming that the curve $A B$ is a change in the photocurrent $I_{\text {excit }}(\lambda)$ under the action of excitation only (see Fig. 4.1.A), whereas the ADE curve is the result of the combined action of excitation and quenching. Then $\mathrm{I}_{\mathrm{CE}}(\lambda)=$ $I_{A B}(\lambda)-I_{A D E}(\lambda)$. The CE part of the graph in Fig. 4.1.B obtained by this method reflects the behavior of the curve $I(\lambda)$ to the left of the point $D$, if there was no excitation process of the crystal.

We got the same result by another calculation method. This plot was selected EH curve $I_{\text {main }}(\lambda)$ 
Fig. 4.1.B. This plot was selected EH curve $I_{\text {main }}$ ( $\lambda$ ) Fig. 4.1.For this area is no longer affected by the excitation of the main light (curve $A B$, the end of the curve Fig. 4.1.A), but the mechanisms forming the minimum current behind the H-point are not yet essential. The expression for the trend line was used for calculations. On the site of the $\mathrm{EH}$ function $I_{\text {main }}(\lambda)$ is approximated by the expression $I(\lambda)=a \lambda^{3}+b \lambda^{2}+c \lambda+d$, where $\mathrm{a}=0,0002 ; \mathrm{b}=-0,5 ; \mathrm{c}=499,08 ; \mathrm{d}=$ -165663 . By extrapolating this dependence to the intersection with the value of $I_{\text {main }}$, we again obtain the curve CE (dotted line Fig.4.1.B).

Practically coinciding curves on the SE site indicate the existence of quenching in the spectral region of $900-920 \mathrm{~nm}$ even before the short-wave boundary of the IR effect.

4. In some cases, in the region of the bifurcation point, we observed a complex dependence of the $I_{\text {main }}(\lambda)$ curve with one or even two inflection points. This can be easily explained by the fact that the simultaneous processes of quenching and excitation depend on the color of the light in different ways, both of which are nonlinear. The predominance of one of them for each wavelength of the incident light and generates a change in the nonlinearity of the graph.

Thus, all four of these arguments indicate that the region of the beginning of the infrared quenching of the photocurrent is characterized by a competition of excitation and quenching, and at the very point $\mathrm{D}$ the intensity of these processes are the same.

\subsection{Dependence of the spectral position of the short-wave boundary of infrared quench- ing on external factors}

With increasing temperature, the boundary of the effect of infrared quenching of the photocurrent $\lambda_{0}$ shifted towards large wavelengths (Fig. 4.2.A).

The operating temperature range was chosen in such a way that at the selected light intensities the effect of temperature quenching of the photocurrent was not affected. A noticeable decrease in the photocurrent was observed, starting with temperatures $\sim 50-55^{\circ} \mathrm{C}$. Using sub- threshold values of temperatures for this effect, the emission of holes from R-centers into the valence band was excluded from consideration.
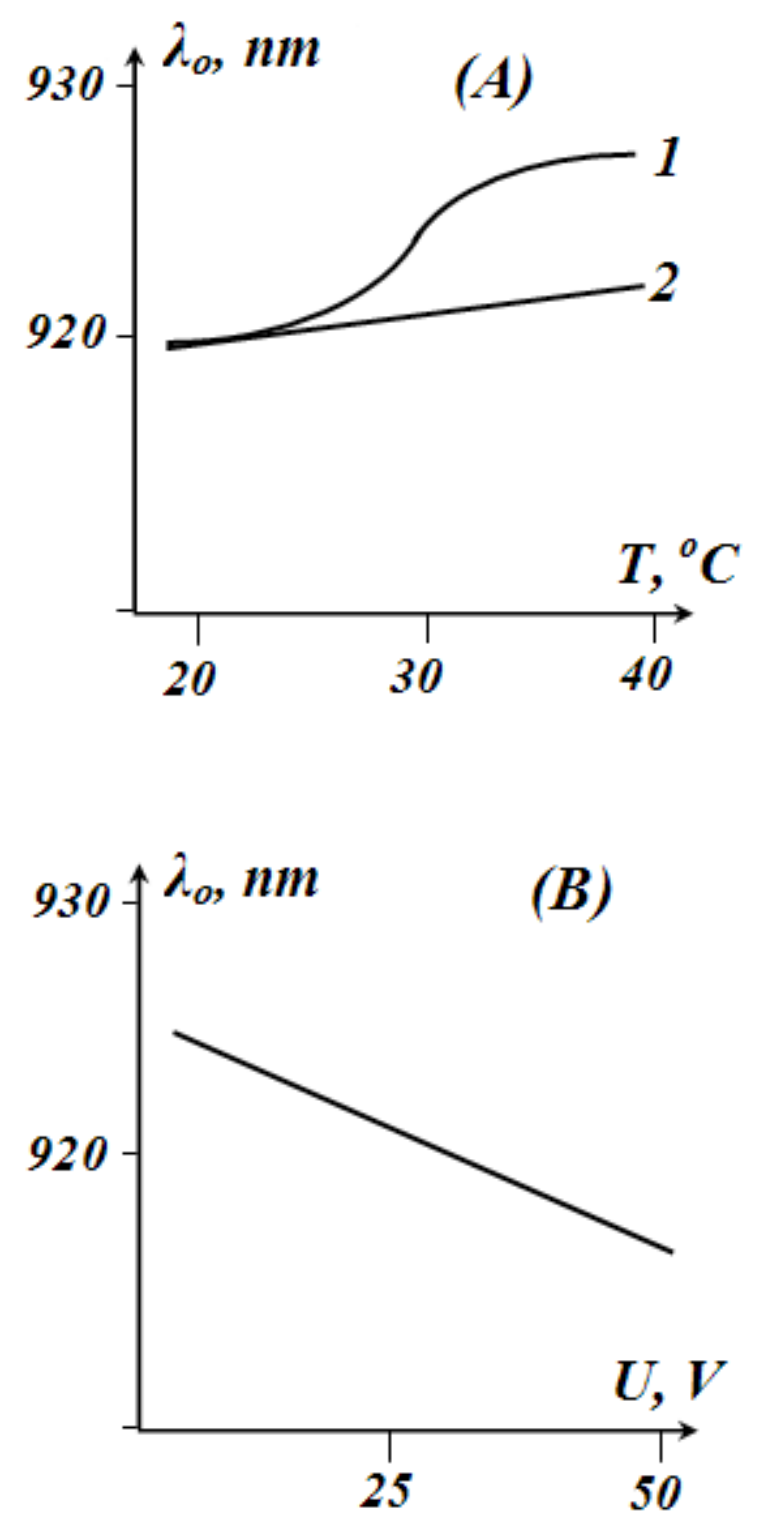

Fig. 4.2. The dependence of the coordinate of the bifurcation point on the operating temperature at high (2) and low (1) intensity of natural light (A) and the change of its position with the increase in the applied voltage (B).

However, thermal transitions occur. By absorbing phonons, equilibrium holes can pass from the basic levels of $\mathrm{R}$-centers with an energy of $1.1 \mathrm{eV}$ to excited R' - centers with an energy of $0.9 \mathrm{eV}$. In this case, the population of 
R-states by holes decreases, and R' - states naturally increases. It has already been noted above that this process is responsible for the fact that the first maximum of optical quenching of the photocurrent with a wavelength of about $\sim 1100$ $\mathrm{nm}$ is always lower than the second, located at a wavelength of 1380-1400 $\mathrm{nm}$.

The first minimum current (Fig. 4.1.B) as closer to the bifurcation point, has a major influence on the spectral position of the onset of the photocurrent IR-quenching effect. Moreover, in accordance with [9], with the change in temperature, the spectral position of this maximum did not change.

As the temperature increases from room temperature and above, the concentration of holes captured on the ground States of R-centers decreases. With a constant number of photons incident on them per unit time, a decrease in the population of these levels is accompanied by a decrease in the transitions of holes in the free state.

As a result, due to the weakening of the quenching mechanism, the equilibrium at the bifurcation point is disturbed, and it moves towards large wavelengths. Here, a new balance is achieved for less intensity of photoexcitation, but increased intensity of quenching. The shift will occur until the increase in the quenching rate compensates for the losses associated with the effect of temperature. The processes are nonlinear. This explains the deceleration of the wavelength increment at the point of branching with increasing temperature. The growth in terms of absolute values, the increment is affected to a lesser degree. Light intensity in the measurement of the dependence $\lambda_{o}(\mathrm{~T})$ (curve 1 Fig. 4.2.A) selected by us according to the figure. 1.1 chapter 1 [1]. With more significant illuminations, the step-like nature of the transition disappeared with additional light. The curve slightly increased (graph 2 Fig. 4.2.A) when values $\lambda_{o}$ in the lower shelves. We explain this by changing the mechanism of emptying the ground state of R-centers.

At high intensities of its intristic light creates a lot of free holes. The filling of R-centers is significant. Their emission, and accordingly, the intensity of the quenching process is controlled only by the flow of IR photons. And the population remains stable. The flow of nonequilibrium holes on R-centers compensates for their knocking out by phonons.

On the contrary, at low light $L_{\text {excit }}$ and, hence, weak filling of R-centers, the quenching process is determined by the concentration of trapped holes, since their number is less than the density of the photon flux.

Thus, the form of the curve $\lambda_{o}(\mathrm{~T})$ is an indicator of the change of the described mechanisms.

The investigated samples had a linear current-voltage characteristic in displacements from 10 to $50 \mathrm{~V}$ over the whole range of the used intensities of the light of its own. Within these values, with increasing voltage, the bifurcation point shifted almost linearly towards short wavelengths.

The results obtained correspond to the model developed in [10].

Since the intensities of the main and additional light did not change during the experiment, the processes of photoexcitation of both the main (electrons through the forbidden zone) and non-main (holes from the R-centers) remain the same. Accordingly, the concentration of the captured charge on the $\mathrm{R}$-centers remains unchanged.

If the applied voltage has almost no effect on the concentration of the free charge responsible for the formation of the current, it changes the speed of its movement, which is reflected in the current in accordance with the dependence $j=e n v$. It is taken into account that the current is formed by the main carriers, in our case - electrons.

However, this is not enough to change the balance of excitation and quenching processes at the bifurcation point. The current electrical voltage not only accelerates the free electrons, (the recorded current increases), but also the photoexcited holes (by increasing the recombination at the S-centers, the current must decrease). For these reasons, the coordinate of the bifurcation point with the change of voltage should not change.

But the processes overlaps with another one. Photoexcited holes are located in the vicinity of the original R-centers and have the ability to re- 
turn there. The greater the applied voltage, the more effectively they get carried away from their traps (see chapter 5.1). This increases the quantum yield for IR light (See chapter 5.2) [11].

This process breaks the symmetry. The recombination at the S-centers is enhanced due to the additional charge. Due to enhanced quenching, the bifurcation point shifts to shorter wavelengths, where equilibrium is restored by a higher level of photoexcitation.

The behavior of the bifurcation point can serve as a criterion for changing the quantum yield from R-centers.
Note that the reasoning is valid only in the region of small intensities of light fluxes, when the number of absorbed light quanta at R-centers is less than the number of holes captured on them. In the opposite case, for example, the very large quenching of the light and a little exciting, $L_{\text {excit }}$ $<<L_{\text {main }}$, the observed pattern may be substantially adjusted by the rate of occupation of R-centers. The limits of applicability of light flux intensities are discussed in more detail in [10,11].

Changes in the position of the short-wave boundary of the IR effect with an increase in the intensity of the main color (horizontal columns

Table. 4.1.

Wavelength $\lambda_{0}$ branch points under various lighting conditions

\begin{tabular}{|c|c|c|c|c|}
\hline & & \multicolumn{3}{|c|}{ The intensity of the excitation light $L_{\text {excit }}, I x$} \\
\hline & & 3 & 5 & 8 \\
\hline \multirow{3}{*}{ 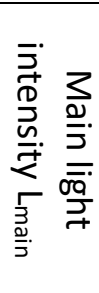 } & $\begin{array}{c}7 \cdot 10^{13} \\
\mathrm{sm}^{-2} \cdot \mathrm{s}^{-1}\end{array}$ & $920 \mathrm{~nm}$ & $908,5 \mathrm{~nm}$ & $897,7 \mathrm{~nm}$ \\
\hline & $\begin{array}{l}10 \cdot 10^{13} \\
\mathrm{sm} \mathrm{m}^{-2} \cdot \mathrm{s}^{-1}\end{array}$ & $925,9 \mathrm{~nm}$ & $915,5 \mathrm{~nm}$ & $903,3 \mathrm{~nm}$ \\
\hline & $\begin{array}{l}13 \cdot 10^{13} \\
s m^{-2} \cdot s^{-1}\end{array}$ & $930 \mathrm{~nm}$ & $920 \mathrm{~nm}$ & $906 \mathrm{~nm}$ \\
\hline
\end{tabular}

With increasing intensity of the exciting light (horizontal lines of table 4.1), the IR quenching boundary shifted towards shorter wavelengths $[12,13]$. These changes are easy to interpret for geometric reasons. The graph Fig. 4.1. would the increase in light intensity corresponds to an increase $L_{\text {excit }}$ horizontal line $I_{\text {excit }}$. The dependence of the $I_{\text {main }}(\lambda)$ does not change. Therefore, the bifurcation point should move to the left.

Physically, this means that with the increase of the initial intensity of the natural light, the balance of excitation and quenching processes at the short-wave boundary of the effect is disturbed. There is an additional generation of electrons, while the number of holes knocked out from the R-centers remains the same, since the number of absorbed infrared photons has not changed. Since the intensity of the main light does not change, it is possible to restore the equilibrium only by shifting the bifurcation point to the short-wave part of the spectrum, where the light is better absorbed and the process of photoexcitation is greater. of table 4.1) are not amenable to simple interpretation [12,13]. In this case, the horizontal line in Fig. 4.1.B remains unchanged, while the dependence of the $I_{\text {main }}(\lambda)$ is nonlinearly modified. In the short-wave part of the graph, it increases due to additional absorption of photons of its own light, whereas in the long-wave part, where interband transitions do not occur, the photocurrent should decrease due to an increase in the number of infrared photons absorbed at the R-centers.

At the bifurcation point, the intensity of both processes-excitation and quenching-increases, but in different ways. The increase in the number of photons of its own light causes a direct increase in the concentration of electrons, and with it more or less a linear increase in the photocurrent.

The increase in the number of photons absorbed at the R-centers can affect the photocurrent only when the knocked holes fall on the S-centers and cause additional recombination of electrons. As shown in [13], this process may 
be affected by the return of holes to the initial center immediately after excitation. At the same time, the quantum yield is generally reduced, and the process of exposure to IR photons is not so effective. As a result, the intensity of the quenching growth lags behind the growth of excitation. In addition, the number of incident photons is already greater than the number of holes on the centers at the used IR light intensities. Further increase in their number cannot cause an increase in the number of transitions. The resumption of the balance is possible in the longer wavelength region, when the process of photoexcitation is less, but the rate of quenching increases. Indeed, the shift of the bifurcation point to the right was observed experimentally.

Studies have shown that the very boundary of the beginning of the infrared quenching of the photocurrent carries important information about the nuances of the processes [20]. Previously, this aspect remained unexplored.

It is found that this spectral region is characterized by a competition of photoexcitation and photocurrent quenching. It is because of this that the wavelength of the short-wave edge of the IR quenching is sensitive to external influences.

In particular, its change with the applied voltage indicates that IR photons knocking holes from R-centers occurs in two stages-part of the photoexcited carriers can return to the original center, not participating in the effect of infrared quenching.

As the intensity of the additional light increases, the effect boundary shifts towards shorter wavelengths due to an increase in the concentration of the main carriers. On the contrary, the increase in the main light leads to the movement of the boundary to the right due to the predominance of the photoexcitation rate over the quenching due to the insufficiently effective ejection of holes from the R-levels.

Similar changes occur with increasing temperature. This is caused by a decrease in the population of the R-centers ground state holes [14].

The spectral position of the region of the infrared quenching can be the indicator of the occurrence of these processes.

Changing the position of the IR quenching edge can be used to create a new type of spec- tral-sensitive sensor $[12,13,15]$. Depending on the calibration applied, it can be used simultaneously to measure temperature and/or voltage and light intensity in the visible and IR region.

At the same time, since the difference current at the bifurcation point is zero, the sensitivity of such a device can be very significant. Depending on the doping of the initial crystal, it is possible to control the spectral position of the bifurcation point.

A more flexible option is also possible - since the spectral position of the bifurcation depends on the applied voltage, this point of increased sensitivity can be adjusted electrically in the finished sensor directly during operation.

The inverse problem is also feasible - with fixed parameters of external action, the coordinate of the point $\mathrm{D}$ can be used to calibrate the wavelength of radiation.

\section{Experimental evidence of the holes os- cillations under R-centers photoexcitation}

The reason for the sliding of the short-wave threshold of the beginning of infrared quenching with external voltage (Chapter 4) is the possibility of repeated captures of holes knocked out by infrared photons from the centers of slow recombination. This is a natural assumption, since the newly activated hole is spatially in the area of the trap, the capture section of which has not changed. But with the departure of the hole changed the charge on the trap, and there were electric forces that contribute to the reverse capture of the already free hole. In addition, it is, as usual, beneficial to reduce their energy. Moreover, the probability of this event in these holes is much greater than that of other free charges of non-main carriers, which in the course of chaotic motion still need to meet with R-centers.

The possibility of re-capturing, as described In section 1.2, may significantly limit the applicability of the expression (1.9) to Q ( $L_{\text {quench }}$; $\left.L_{\text {excit }}\right)$, especially in the region of low light intensities. For a small level of exciting light, the concentration of captured holes on the R-centers is too small, and with insufficient intensity of infrared radiation, they are too little knocked out. 
Repeated captures begin to play a decisive role. Until the disappearance of the General effect of infrared quenching photocurrent, although both lights still continue to operate.

The existence of similar, probably multiple, oscillations of holes and the impact of these processes on the observed photovoltaic properties of the samples in the literature up to the present time was not considered. Although this issue has a wider importance, because it fundamentally applies to any emission from the traps.

The effect of infrared quenching in this case acts only as a convenient and sensitive tool to confirm this phenomenon. It is the combination of inherently effective hole traps and effective recombination S-centers that makes this process convex. The measured current consists of the main carriers - electrons. Holes knocked out from R-centers carry electrons to recombination, which is reflected in the magnitude of the flowing current. If there were only hole traps in the crystal and the current was determined only by free holes, then they could take part in the current transfer only up to the moment of repeated captures to the neighboring R-centers. Since the usual concentration of these centers is high $\left(\left(\sim 10^{15} \mathrm{~cm}^{-3}\right)\right.$ and comparable, and at low light intensities even more concentration of free holes, such phenomena would be hardly noticeable due to the small free path.

\subsection{Dependence of the spectral distribu- tion of photocurrent quenching on the ap- plied voltage}

External voltage, on the contrary, prevents re-capture, because it helps to remove holes from the parent centers. Therefore, we used this parameter to test the assumption of oscillation.

For Fig. 5.1. the curve (b) is measured at the best ratio of the intensities of the exciting light to the quenching light (See chapter 1.1, Fig. 1.1), when the infrared quenching coefficient reached the highest value $[9,16,17]$. The sample was applied with $20 \mathrm{~V}$. the range of voltages used was selected from the linearity of the current-voltage characteristics to avoid the additional influence of pre-breakdown phenomena.
As can be seen from the figure, the rise in voltage increases both the maximum $Q(\lambda)$. Moreover, this behavior was typical for all combinations $L_{\text {quench }}$ and $L_{\text {excit }}$ so far the effect of IR-quenching of the photocurrent was well observed.

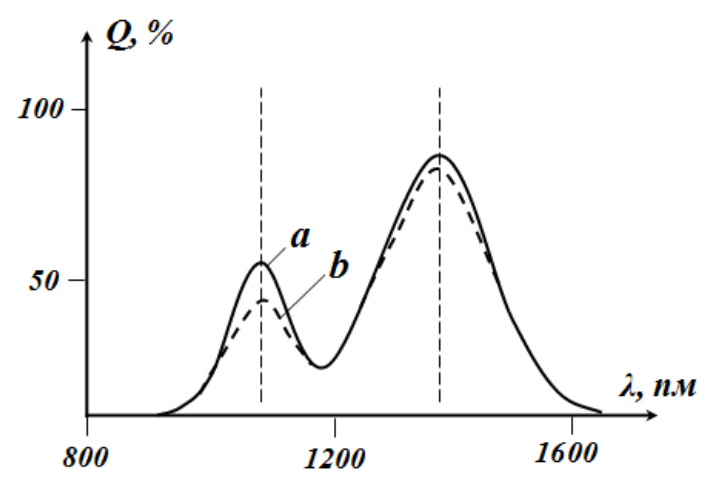

Fig. 5.1. Spectral distribution of the quenching value on the applied electric field: a) - 50 $\mathrm{V}$ is applied to the sample; $b)-20 \mathrm{~V}$ is applied to the sample.

In both cases, the second maximum was higher than the first one due to the thermal redistribution of holes between the centers of slow recombination. With an increase in the applied voltage, an increase in this difference was observed. But in different ways. For the maximum in the range of $1080-1100 \mathrm{~nm}$ it was more significant.

This is explained as follows. Since the temperature has not changed, the intensity of the hole transitions from $\mathrm{R}$ to $\mathrm{R}^{\prime}$ - levels remains fixed. An increase in the applied voltage reduces the number of re-captured holes for both levels. Moreover, judging by the quantum yield (see chapter 5.2), it is an essential channel for the steady-state population of the centers. However, the decrease of this flow for the ground and excited States of R-centers affects differently. From the ground state (at a depth of $1.1 \mathrm{eV}$ ) holes are knocked out thermally and with an increase in voltage less return. Both mechanisms are aimed at reducing their concentration at this center. On the contrary, for R' -levels $(0.9 \mathrm{eV})$, these mechanisms compete. If the stress reduces their population, the thermal swap still increas- 
es. This camouflages the field effect on the population of the excited state of the R-centers. This is reflected in a smaller change in the long-wave maximum in Fig. 5.1.

It should be noted that with an increase in voltage, due to the movement of free holes, the hole component of the photocurrent increases. And after the capture in S-centres they are in accordance with the Bube-Rose mechanism needs to call it blanking out. Thus, the reduction of repeated hole captures and their participation in the current transfer is a competing mechanism with respect to the value of $\mathrm{Q}$. Since the capture cross sections for holes and electrons at the centers of the first class are equal, the appearance of additional holes should cause an equal decrease in the concentration of electrons in the conduction band and a corresponding decrease in the photocurrent. At the same time, due to the increase in the drift velocity of both electrons and holes, as well as the increase in the concentration of free holes, the photocurrent should increase slightly. The degree of quenching, i.e. the value of the coefficient $\mathrm{Q}$, decreases slightly.

Of course, removing the hole from the original R-center, the applied voltage contributes to its capture at the S-levels. Then the quenching value and, accordingly, the value of $\mathrm{Q}$ increase. However, during the drift, the holes can be captured at the other $\mathrm{R}$ centers. Moreover, the capture cross-sections for holes on the S- and R-centers are the same and the charge state of the R-centers (See chapter 2.1) contributes to this.

If the value of the quantum yield for infrared radiation would be about the same as the quantum yield for its own light, these two processes would compensate each other. However, the abnormally low $\beta$ value for IR light $[10,11,18]$ makes the inverse oscillation of the holes decisive for the useless absorption of long-wave photons. The application of external voltage breaks this mechanism and is effective, even if some part of the holes and returns to the other R-levels and again take part in the oscillations.

Thus, both changes in the spectral distribution of the infrared quenching coefficient - both the total increase in the value of Q with the applied voltage and the relatively larger jumps of the short-wave maximum-indicate in favor of the mechanism of repeated captures of holes on the R-centers.

Note in conclusion that in some situations the effect of repeated captures in the crystal can be eliminated automatically. Thus, when considering the migration-dependent relaxation of the photocurrent (chapters 3.1 and 3.2), the oscillation phenomenon was not manifested. In this case, it was due to the fact that R-centers accumulated in the area of spatial charge at the contacts. Inner field in SCR had contributed to the outflow of the embossed holes from the centers. The opposite is true. The fact that repeated captures didn't affect, serves as the proof of correctness of the constructed models, both relaxation, and re-capture.

\subsection{Determination of quantum yield for infrared light}

Oscillation of the release of capture did not occur in the externally recorded electric current, such as the coordinate of the charge carriers is not changed. For this reason, these stages of excitation remained unexplored.

In our case, the effect of infrared photocurrent quenching was chosen as a measurement tool. The quantum yield for monochromatic longwave light was directly determined by experiment. It should be assumed that this parameter determines on the one hand the number of free media, and on the other - the number of photons spent on it. The difference is precisely related to the media returns to the original center, which are useless for current generation.

To determine the quantum yield of IR quenching, we applied the formula (1.9), [10,11] derived under the condition of significant light fluxes of exciting and suppressing light. Moreover, the intensity of the quenching is greater than the intensity of the excitation.

It means the number of quants trapped on the front surface of the crystal absorbed in the sample and created free carriers. Taking into account the quantum outputs for light fluxes, the expression for the quenching coefficient has the form 


$$
Q=\left[\left(1-\frac{\tau_{p}}{\tau_{n}}\right)+\frac{L_{\text {quench }} \alpha \beta \tau_{p}}{L_{\text {excit }} \alpha^{\prime} \beta^{\prime} \tau_{n}}\right] \cdot 100 \%
$$

which assumes a linear Q-lux dependence in the infrared region.

Figure 5.2 shows the experimental dependence of $Q$ factor on the intensity of the quenching light of a wavelength of $1100 \mathrm{~nm}$ with the fixed threads of the excitation light. The view of figure 5.2 corresponds to the section of the graph 1.1.b along the vertical line. The shortwave maximum of quenching is chosen as more sensitive to external influences (see Fig. 5.1).

As can be seen from the figure, in the case where the intensity of the exciting light is too small (curve 1) or too large (curve 5) compared to the intensity of the quenching light, the graphs did not contain linear sections. Obviously, for these curves the conditions of derivation of the formula (1.9) were not observed. Thus, these dependencies, (1) and (5) Fig. 5.2, define the limits of applicability of the expression for $\mathrm{Q}\left(\mathrm{L}_{\text {quench }}\right.$; $\mathrm{L}_{\text {excit }}$ ) (see also Section 1.2 and Fig.1.2).

The region of linear dependence was found for curves 2-4 in the range of dampening light intensities (12-25)·1015 s-1·mm-2 at exciting light intensities from 2.6 to $9,8 \mathrm{~lx}$.

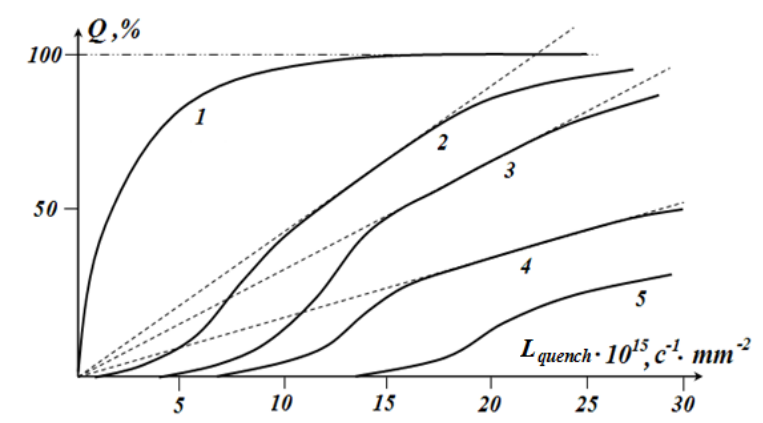

Fig. 5.2. The dependence of the aching value on the number of infrared is incident on the surface of the sample at a fixed excitation level:

$=1.2 l x ; \quad 2 . L_{\text {excit }}=2.6 l x ; \quad 3 . L_{\text {excit }}=4.25$

4. $L_{\text {excit }}=9.8 l x ; \quad$ 5. $L_{\text {excit }}=19.4 l x$.

It can be seen that as the intensity of the exciting light increases, the slope of the graphs 2-4 in the linear region decreases. Extrapolation of the linear sections of curves 2-4 fell into the ori- gin of figure 5.2. According to the formula (5.1), this means that the first term in square brackets, with values, Lquench $=0$ is also equal . In such a case, at least for straight sections, it should . That is, the lifetime of free holes approximately corresponds to the lifetime of free electrons. This is the expected result, since recombination is mainly carried out through S-centers with the same capture cross-section for electrons and holes. Unfortunately, the details of changes in the relationship of the times of life at different intensities of own and exciting light have not been studied. At further calculations it was accepted $\frac{\tau_{p}}{\tau_{n}}=1$

The type of denominator of the second term in (5.1) is not convenient for experimental processing. So he was transformed, given $\mathrm{n}=\mathrm{L}_{\text {excit }}$ $\alpha^{\prime} \beta^{\prime} \tau_{n}$, where $n$ is the concentration of the charge created by their own light. Then $\mathrm{j}=(\mathrm{en} \mu) \mathrm{E}$ was used. Taking into account: $j=\frac{I_{\text {excit }}}{S} ; E=\frac{U}{l}$, where $\mathrm{I}_{\text {excit }}$-current flowing under the action of exciting light only, and $l=1,2 \mathrm{~mm}$ - length of the sample between the contacts $S=1 \mathrm{~mm}^{2}$ - cross section of the sample, we obtain:

$$
L_{\text {excit }} \alpha^{\prime} \beta^{\prime} \tau_{n}=I_{\text {excit }} D,
$$

where the constant $D=\frac{l}{U S \mu e}$.

The value of the voltage $U=20 \mathrm{~V}$ was chosen as the minimum of those used to make the effect brighter, since a small voltage at least interferes with the oscillation (see section 5.1). The mobility value is taken $\mu=210 \frac{\mathrm{cm}^{2}}{V c}$. Thus, under the parameters used

$$
\mathrm{D}=7,14 \cdot 10^{21} \mathrm{~A}^{-1} \mathrm{~m}^{-1} .
$$

After the above transformations, the formula (5.1) taking into account (5.2)-(5.3)

$$
Q=\left[\frac{L_{\text {quench }} \alpha \tau}{I_{\text {excit }} D} \beta\right] \cdot 100 \%
$$

allows you to determine the coefficient of the angle of the curve $\mathrm{Q}\left(\mathrm{L}_{\text {quench }} \mid \mathrm{L}_{\text {excit }}\right)$ : 


$$
\frac{\Delta Q}{L_{\text {quench }}}=\left[\frac{\alpha \tau}{I_{\text {excit }} D}\right] \beta \cdot 100 \% .
$$

The coefficient $\alpha$ was determined by a spectrophotometer CФ-26 at a wavelength of $1100 \mathrm{~nm}$. In the range of output slots of the spectrophotometer from 0.4 to $0.6 \mathrm{~mm}$ was obtained $\bar{\alpha}=0.96$. The lifetime of carriers was determined in two ways - by modulation of illumination and by the phase shift method [19], and was $8 \cdot 10^{-4} \mathrm{c}$.

With this in mind, it is determined: for curve 2 of figure $5.2-\beta_{2}=0,026$; for curve $3-\beta_{3}=0,049$; for curve $4-\beta_{4}=0,072$.

It is seen that the value $\beta$ remains abnormally low in the entire region of the applied photoexcitation intensities. Moreover, the absorption coefficient of long-wave light is close to 1 . This means that for the final release of each hole from the R-center, several tens of IR photons are consumed (in our case, from about 40 to 15 ). The hole repeatedly returns to the original level until the applied field drags it beyond the capture section. Indirectly, this is also evidenced by the changes in $\mathrm{Q}$ with the intensities of both light fluxes and the field considered above.

Some increase $\beta$ with increasing photocurrent, and hence the intensity of their own light is associated with an increase in the population of R-centers. This increases the likelihood of media ejection and reduces the possibility of reseizures.

Thus, it is shown that within the limits of the applied combination of exciting factors - temperature, field and intensities of self and quenching light - when the lifetimes of nonequilibrium carriers of both signs were approximately equal, the calculated value of the quantum yield is in the range $[0,026-0,072]$. This, along with the Lux-ampere and field dependence $\mathrm{Q}$, indicates the presence of a previously unexplored phase of charge excitation from deep traps - before taking part in the current transfer, they can repeatedly return to the initial center $[15,18]$.

The proposed model allows estimating the concentration of the second class centers. For this purpose, the parameters of curve 4 were used at an extremely large, but still working, in- tensity of own light, or, what is the same, the maximum of the observed quantum yields. The abscissa of its deviation from linearity (taken $\mathrm{L}_{\text {quench }}=27 \cdot 10^{15} \mathrm{c}^{-1} \cdot \mathrm{mm}^{-2}$ ), the change of the growth mechanism $\beta$, is treated as the number of photons comparable to the concentration of $\mathrm{R}$-centers. Then the calculation was carried out according to the same algorithm as in section 1.1. First, the proportion of photons from the whole beam that fall on the crystal surface was determined. This was done by the proportion between the light spot and the geometric dimensions of the front surface of the sample. Then it was assumed that the absorbed photons in the crystal are distributed uniformly and their density was calculated $N^{\prime \prime}=8,64 \cdot 10^{14} \mathrm{~cm}^{-3}$. The concentration of recombination R-centers in the investigated crystal is thus of order $9 \cdot 10^{14} \mathrm{~cm}^{-3}$.

\section{REFERENCES}

1. Simanovych N.S., Brytavskyi Ye.V., Kutalova M.I., Borshchak V.A., Karakis Y.N. "The study of heterogeneous sensitized crystals of cadmium sulfide. Part I. About charge state of the centers recombination" // "Photoelectronics", n. 26. Odessa, “Одеський національний університет" 2017. s. 124 - 138 .

2. S.S.Kulikov, Ye.V. Brytavskyi, M.I., Kutalova, N.P. Zatovskaya, V.A. Borshchak, N.V. Konopel'skaya, Y.N. Karakis "The study of cadmium sulfide heterogeneously sensitized crystals. Part II. Relaxation characteristics" // "Photoelectronics", n. 27. Odessa, "Одеський національний університет" 2018. s. 79 - 93. 3. A.A.Dragoev, Yu.N.Karakis, M.I. Kutalova "Studies of processes within short-wave threshold of photocurrent infrared quenching" // Photoelectronics, n. 16. 2007. s. $60-64$.

4. А.А.Драгоев "Вивчення умов початку інфрачервоного гасіння фотоструму” // Работа - призёр Областной сессии МАН. Мала Академія наук України. Одеське територіальне відділення. Секція “Фізика". Одеса, 2007. $31 \mathrm{c.}$

5. Каракис К.Ю. "Релаксационные характеристики полупроводниковых кристаллов 
с ИК-гашением фототока"// Одесса, Работа - лауреат Областного конкурса (III место) Малой академии наук, Областное территориальное отделение, Секция “Физика”. Одесса, 2001. c. 1-37.

6. Ю.Н.Каракис, Н.П.Затовская, В.В.Зотов, М.И.Куталова "Особенности релаксации фототока в кристаллах сульфида кадмия с запорными контактами" // 1-а Українська наукова конференція з фізики напівпровідників. Одеса, 10-14 вересня 2002. Тези доповідей. T.2. - c. 138 .

7. К.Ю.Каракис, В.А.Борщак, В.В.Зотов, М.И.Куталова "Релаксационные характеристики кристаллов сульфида кадмия с ИК- гашением" // Фотоэлектроника вып.11. 2002. c. $51-55$.

8. Каракис Ю.Н., Борщак В.А., Затовская Н.П., Зотов В.В., Куталова М.И., Балабан А.П. "Исследование релаксации фототока в полупроводниковом устройстве" // Фотоэлектроника №12. 2003. с. 132 - 135.

9. M.A.Novikova, Yu.N.Karakis, M.I. Kutalova "Particularities of current transfer in the crystals with two types of Recombination centers" // Photoelectronics n.14. 2005. s. 58 -61.

10. A.A.Dragoev, Yu.N.Karakis, M.I. Kutalova "Peculiarities in photoexcitation of carriers from deep traps" // Photoelectronics n. 15. 2006. s. 54-56.

11. Драгоев А.А., Затовская Н.П., Каракис Ю.Н., Куталова М.И. "Управляемые электрическим полем датчики инфракрасного излучения" // Материалы 2 nd International Scientific and Technical Conference "Sensors Electronics and Microsystems Technology" Book of abstracts s. 115. Секция IV "Радіаційні, оптичні, та оптоелектричні сенсори”. Україна, Одеса, 26-30 червня 2006 р. “Астропринт”. 2006.

12. Зимина София Олеговна, Каракис Юрий Николаевич "Исследование полупроводникового спектрального калибратора с селективной чувствительностью" // Материалы международной заочной научно-практической конференции "Инновационные подходы и современная наука" - Новосибирск. 2012. c. $20-26$.
13. Зимина С.О., Каракис Ю.Н. “Разработка физических основ схем регистрации в ближней инфракрасной области" // Международная конференция “Электронная техника и технологии". Харьковский национальный университет радиоэлектроники. Харьков. 2011. Тезисы докладов. Том 1. “Электронные приборы и компоненты, включая микрои наноэлектронные". с. 106.

14. Melnik A.S., Karakis Y.N.. Kutalova M.I., Chemeresjuk G.G. "Features of thermo-optical transitions from the recombination centers excited states" // Photoelectronics n. 20. 2011. s. 23-28.

15. Софія Зіміна, Юрій Каракіс. "Спектрально-чутливий датчик світлових потоків, температури та напруги“ // International Conference of Students and Young Scientists in Theoretical and Experimental Physics HEUREKA - Lviv, Ukraine - 2011. - Book of abstracts. s. F3.

16. Новикова М.А. “Особливості інфрачервоного гасіння фотоструму у напівпровідниках CdS" // Работа - лауреат Областного конкурса (1 место) Малой академии наук, Областное территориальное отделение, Секция “Физика”. Одесса, 2005. с. $1-37$.

17. M.A.Novikova "Change of Photoelectric Properties of Semiconductors as a Tool for the Control of Environmental Pollution by Extraneous Admixtures and IR-illumination"

//Section of Environmental Science. Finalist of Intel International Science and Engineering Fair. USA, AZ, Phoenix, May 8-18. 2005.

18. А.А.Драгоев "Визначення квантового виходу інфрачервоного гасіння фототоку" // Робота - лауреат Областної сесії Малої Академії наук України. Одеське територіальне відділення. Секція “Фізика". Одеса 2006. 32 c.

19. Чемересюк Г.Г., Каракис Ю.Н. Методические указания к лабораторным работам по спецпрактикуму “Фотоэлектрические процессы в полупроводниках. Часть I.” // Одесса. Издательство Одесского национального университета. 2011. с. 1 - 59.

20. 13. L.M. Filevska. Luminescence of 
nanoscale tin dioxide. Review. Photoelectronics. 27 (2018), p.52-59.

21. 12. V.S. Grinevych, L.M. Filevska, V.A. Smyntyna, M.O. Stetsenko, S.P. Rudenko, L.S. Maksimenko, and B.K. Serdega. Characterization of $\mathrm{SnO} 2$ Sensors Nanomaterials by Polarization Modulation Method. Springer Science+Business Media Dordrecht $2016 \mathrm{~J}$. Bonca, S. Kruchinin (eds.), Nanomaterials for Security, NATO Science for Peace and Security Series A: Chemistry and Biology, DOI 10.1007/978-94-017-7593-9, p.259-266.

UDC 621.315 .592

S. S. Kulikov, Ye. V. Brytavskyi, V. A. Borshchak, N. P. Zatovskaya, M. I. Kutalova, Y. N. Karakis

\section{THE STUDY OF HOMOGENEOUS AND HETEROGENEOUS SENSITIZED CRYSTALS OF CADMIUM SULFIDE. PART III. OSCILLATIONS OF EXCITED CARRIERS}

The processes at short-wave limit of the quenching of the photocurrent were studied. The possibility of creating a new type of device - a sensitive photometer (not on the intensity of light, but on its wavelength), and the combined temperature-voltage tester.

The process of hole oscillation under photoexcitation from R-centers is investigated. The quantum yield for infrared light is determined. The effect of the applied voltage on the form of the spectral distribution curves of the photocurrent quenching was found and explained. The concentration of R-centers in the samples is calculated.

This publication is a continuation of the reviews [1-2]. For the sake of preservation of generality of work continuous numbering of sections is chosen. Numbers of formulas and figures are presented by sections. References in each article are given individually.

Cadmium sulfide crystals are used in our studies as a convenient model material. Obtained results and constructed models are also applied to other semiconductors.

УДК 621.315 .592

С. С. Куликов, Е. В. Бритавский, В. А. Борщуак, Н. П. Затовская, М. И. Куталова, Ю. Н. Каракис

\section{ИССЛЕДОВАНИЕ ОДНОРОДНО И НЕОДНОРОДНО ОЧУВСТВЛЁННЫХ КРИСТАЛЛОВ СУЛЬФИДА КАДМИЯ. ЧАСТЬ ІІІ. ОСЦИЛЛЯЦИИ ВОЗБУЖДЁННЫХ НОСИТЕЛЕЙ}

Изучены процессы на коротковолновой границе гашения фототока. Показана возможность создания прибора нового типа - как чувствительного фотометра (но не на интенсивность света, а на его длину волны), так и комбинированного тестера температура-напряжение.

Исследован процесс осцилляции дырок при фотовозбуждении c R-центров. Определён квантовый выход для инфракрасного света. Обнаружено и объяснено влияние приложенного напряжения на вид кривых спектрального распределения гашения фототока. Вычислена концентрация R-центров в образцах.

Настоящая публикация является продолжением обзоров. Ради сохранения общности работы нумерация разделов выбрана сквозной. Номера формул и рисунков представлены по разделам. Ссылки на литературу в каждой статье даются индивидуально.

Кристаллы сульфида кадмия использованы в наших исследованиях какудобный модельный материал. Полученные на них результаты и построенные модели распространяются также на другие полупроводниковые вещества.

Ключевые слова: сульфид кадмия, фотовозбуждение, гашение фототока 